\title{
MODERN COMPETENCIES IN THE TECHNO-CULTURE OF FUTURE TECHNICAL SPECIALISTS
}

\author{
Gulnoza Alimjonova
}

Independent Researcher Fergana Polytechnic Institute, Uzbekistan

\section{ABSTRACT}

The article analyzes the modern pedagogical conditions, factors, stages, components, methods of developing the techno-cultural culture of students of higher technical education institutions. The article also explores the pedagogical mechanisms of ensuring the integration of social and technical knowledge in the formation of axiological attitudes in the conduct of technical creative activities of students.

KEYWORDS :- Education, higher education, higher technical education, technology, ethics, techno-ethics, technical creativity, axiological attitude, humanitarian knowledge, technical knowledge, integration.

\section{INTRODUCTION}

In the life of modern society, technical activity professional, based on scientific knowledge, socially responsible and human-sized design and operation of technical devices - plays an everincreasing role. Modern technical professionalism presupposes not only mastering the scientific foundations of engineering design, but also an awareness of the goals, meanings and tasks of engineering as a whole, its place in the culture of the 21st century. Of great importance is the understanding of the social responsibility of engineering for the transformation of natural and social space, the need to commensurate transformative efforts with the controlling capabilities of a person. Engineering ethics, which establishes the compliance of engineering activities with the criteria of social efficiency, acceptability and safety, becomes part of the professional culture of an engineer. Over the past century, from disparate tools of human influence on individual elements of the natural environment, technology has turned into a powerful socio-technical system, a techno-sphere, which has created a new habitat that has influenced the scale of cultural universals, has changed the rhythms and patterns of sociocultural life, that is, it has become active part of the socio-cultural space. The sphere of moral regulation includes new types of interaction: technology and society, technology and man, technology and nature, technology and the global development of mankind. The socio-cultural consequences of the implementation of technical solutions, which are reflected in the ethical codes of professional societies, are discussed.

The main topics of ethical codes are: 1) norms and standards of socially oriented engineering, 2) technological algorithms that maximize the positive and minimize the negative consequences of the impact of technology on the natural and artificial environment, 3) the social competence of an engineer as a part of professional culture, before total social responsibility for their activities [1]. 
CURRENT RESEARCH JOURNAL OF PEDAGOGICS 2(6): 78-84, June 2021

DOI: https://doi.org/10.37547/pedagogy-crjp-02-06-16

ISSN 2767-3278

(C)2021 Master Journals

\section{Crossref do) 81 Google}

Accepted 18 th June, 2021 \& Published 23 ${ }^{\text {th }}$ June, 2021

Understanding of professionalism both in scientific literature and in regulatory codes includes, along with professional competence, social responsibility and personal maturity, which implies conscious adherence to the norms of ethical codes, the ability to consider a problem or situation in the future, taking into account all its social, environmental and other consequences for society, the ability to highlight in engineering problems and projects that seem at first glance to be exclusively technical, civil and ethical aspects. Engineering activity involves the regular and systematic application of scientific knowledge to create artificial (technical) systems of machines, devices, etc. This is its difference from a simple technical activity, based more on experience, guess, common sense. The first stage in the development of engineering activity (called classical) includes the formation of a new class of professionals who have received serious natural science training and the skills to use it to create and design technology. Rational understanding of its activities, understanding of its responsibility and broad social influence led to the creation at this stage of the first codes of ethics, which expressed public concerns and expectations.

\section{Materials AND Methods}

At this stage, engineering ethics represented by the founders of the first engineering societies [2] formed, relying on the philosophy of technology (E. Kapp, F. Dessauer, P.K. Engelmeyer), the idea of the social service of technology, assessed the influence of technology on social development and human characteristics. The norms of responsible behavior of an engineer influencing changes in nature and society were formed. But the real mechanisms of public opinion that could influence specific procedures for the design and use of technical devices have not yet taken shape.

The modern stage of development of technical activity is characterized by a systematic approach to solving complex scientific and technical problems, which is possible only by addressing the entire range of natural, technical, as well as social and humanitarian sciences. In the information society, new forms of engineering and design culture, new systemic and methodological orientations are being formed, using, together with technical techniques and skills, humanitarian methods of cognition and transformation of reality.

\section{Results AND DISCUSSION}

This significantly changes the procedures for the ethical regulation of engineering activities. It is no longer enough to think exclusively in the context of social responsibility. The implementation of the most complex socio-technical projects cannot depend on the personal virtues of the performers, but must be carried out within the framework of compulsory socio-cultural expertise, including moral assessment. Of course, a personal understanding of the social consequences of their activities and the desire to act in the safest possible way are also important, they are necessary, but not sufficient conditions for socially effective engineering activity. The concept of efficiency includes, along with the prevention of dangerous consequences, understanding the ways of positive development of society. The ethical principles of regulation include not only prohibitions on socially dangerous actions, but also development norms that focus on reorganizing society on more equitable grounds. What are these perspectives, how can they be achieved through professional activity? These questions are discussed in contemporary techno ethical ethics.

American techno-ethicists speak of two models of professionalism in modern engineering, each one focused on social effectiveness. The first (business model) assumes as the basis of engineering activities the desire to make a profit, to implement 
CURRENT RESEARCH JOURNAL OF PEDAGOGICS 2(6): 78-84, June 2021

DOI: https://doi.org/10.37547/pedagogy-crjp-02-06-16

ISSN 2767-3278

(C)2021 Master Journals

\section{Crossref dof 81 Google}

Accepted 18 th June, 2021 \& Published 23 ${ }^{\text {th }}$ June, 2021

new promising projects, but with the inevitable understanding that engineering activities are committed to the public good and the maximum benefit can be obtained only on the path of observance of moral standards and orientation to ethically impeccable activities. ... The second model (existential) is aimed at social development, at serving the benefit and safety of society and the desire to use their knowledge and skills to choose the most effective means of achieving public good. Society, American researchers are sure, rewards professional work that includes a socially responsible and human developmental component [3].

In the last third of the twentieth century, both the object of engineering activity is changing (instead of a separate technical device, mechanism, machine, etc., complex man-machine systems are designed), and the structure of the engineering activity itself, which includes organizational, managerial, and marketing activities. To carry out such integration, special specialists were required - system engineers who, along with technical and natural science, possess a complex of social and humanitarian knowledge. All modernization projects in the field of education are aimed at the formation of specialists of this new type.

The actual practice of technologically advanced countries goes further and sets new requirements for engineering activities. Exit of engineering activity beyond the design of only humanmachine complexes into the sphere of socioeconomic and socio-cultural contexts of ensuring the functioning and development of these complexes leads to the formation of a new stage of engineering - socio-technical design [4]. Engineering and design are reversed. If traditional design was part of engineering, then socio-technical design includes engineering activities along with other types of social practice to ensure the socially safe and personalityoriented functioning of human-machine systems (creation of social infrastructure, maintenance, consumption, training of personnel, project management, etc. innovation), not just machine production. The understanding of engineering is also changing. In the modern world, this is not just the design of technical devices, but the activity of designing a social space, which should be environmentally and socially safe, compatible with public demands and opportunities.

Accordingly, the ethical environment for discussing technical projects should be transformed. In an innovative society, it is extremely difficult to predict the consequences of the implementation of a particular project, because any innovation is fraught with risk, with unpredictable consequences. This is especially evident in the development of nanotechnology [5]. Standard codes of ethics are not sufficient for dealing with situations of uncertainty. An engineer can only make a decision based on the general moral principles of social efficiency as the only reliable compass in the raging ocean of social risks. Moral norms must be understood by him, accepted, updated and verbalized in professional communication. Moral principles provide a solid foundation for dealing with uncertainty. Therefore, the importance of engineering ethics in the risk society is increasing. For its development and improvement, an ethical environment is necessary, which in modern conditions should be formed by a technical university. In the industrial era, engineering ethics was reduced to the responsibility of the engineer for the social consequences of a technical project and the need to defend his point of view, which was reflected in codes of ethics. But, strictly speaking, informing the public about the dangers or objection to the leader is not actually a moral action. This can be a manifestation of both professional qualities and established corporate relations. In an age of innovation, confronting bossy opinion cannot be the job of a lone engineer. Effective design and 
CURRENT RESEARCH JOURNAL OF PEDAGOGICS 2(6): 78-84, June 2021

DOI: https://doi.org/10.37547/pedagogy-crjp-02-06-16

ISSN 2767-3278

(C)2021 Master Journals

\section{Crossref dof 81 Google}

Accepted 18 th June, 2021 \& Published 23 ${ }^{\text {th }}$ June, 2021

implementation of socio-technical systems is possible only if engineering problems are discussed in ethical terms by the engineering community as a whole, and it is impossible to make morally irresponsible decisions without prejudice to their professional reputation. Technoethics teaches us to live and work in a moral climate.

Modern technoethical ethics cannot be limited to the category of responsibility of an engineer for a technical project. In the conditions of collective work on socially significant projects, a lone engineer cannot, and should not, confront other project participants with his own separate opinion. Public safety and responsible execution of tasks are not a matter of ethics, but of labor discipline and administrative norms of technical activity. Violation of them is not an area of ethical responsibility. The purpose of ethics is to provide a basis for making a decision in a new situation, when the consequences are not clear, and the goals and methods are new and unpredictable [6].

Ethical regulation is necessary at the stage of choosing a project, searching for means and methods for its implementation, discussing intermediate results, where they lead, whether they achieve the intended goals or deviate in an unsafe direction. For this, public opinion should form and successfully operate mechanisms for discussing the goals and objectives of technical activities, institutions for the transmission of ethical positions among the general population, their ability to influence and monitor the implementation of technical projects. The engineering community in its group environment should also focus on the ethical problematization of technology, be familiar with the moral principles of regulating activities and methods for discussing controversial issues. Ethics should be considered the only acceptable and reliable basis for decision-making in a professional environment. Then an individual engineer will not have to violate production discipline and "wash dirty linen in public", turn to the public for support, and so on. Ethical regulation should be immanent to the production team, the engineering community as a whole.

And for this, moral education is important, teaching moral thinking in the course of university education.

So, the ethical regulation of engineering is of particular importance in a society based on innovation and a constant search for technical solutions, associated with the uncertainty and unpredictability of social consequences. Preparing an engineer for professional activity in such conditions implies the development of social and personal competencies that allow making decisions in a risk situation, relying on sociocultural experience and socially safe and effective strategies of behavior. And morality is precisely such a historically tested system of socially friendly behavior that equips a person with a system of coordinates in difficult social conditions. Willingness and the ability to apply moral principles should educate a modern university in the course of professional ethics.

We know that the rapid growth of naturalscientific and technical knowledge has supplanted the educational component from the educational process, reducing the concept of professionalism to the possession of operational technical procedures. By the way, moral issues in the professional sphere have also been reduced to the creation of ethical codes with calls to think not only about their own benefit. But engineering ethics cannot be reduced only to codes, it is only one of the elements of moral regulation. Truly moral reflection on one's behavior, the ability to choose from several options for action, based on ethical standards, for a long time was not practiced in production, and was not brought up at the university. If the practical translation of 
socio-cultural values and culturally appropriate samples of professional activity, previously carried out from mouth to mouth, from hand to hand in production, turned out to be ineffective, unsuitable for each next generation of engineers entering into production life, then in the university the socio-cultural guidelines of professional activity were not indicated in any way. ... Gradually, an ideological vacuum was formed, when a mass engineering education produced a "trained savage", a "civilized barbarian" (H. Ortega y Gasset). Moral regulation as a whole lost its foundation: the weakening of ties between generations, the crisis of the family made it impossible to transmit moral values and the implementation of regulation according to the traditional type from the elders to the younger, and the educational system, the university, above all, remained value-neutral, positivist-minded towards obtaining and mastering new knowledge and technologies. Teaching a course in engineering ethics at a modern university can help replenish the "missing link" of upbringing from the educational space, it is designed to teach engineers to use the possibilities of morality to determine the strategy of their behavior in situations of uncertainty and risk, which is a modern innovative society.

Without appropriate personal competencies, it is impossible to talk about the current level of professionalism [7]. Moral competences seem to be the most important of personal ones, because all the others (leadership, team, etc.) are additional to the worldview and practicalbehavioral. At the university, it is necessary to recreate the educational link in the formation of the personality on a new, modern, technological basis. "The emphasis in the educational process should be shifted from teaching to upbringing, from knowledge to values, from natural science to the humanitarian component of scientific knowledge, from specific information in private disciplines to a holistic scientific picture of the world" [8].

The multilevel nature of modern higher education makes it possible to make the formation of a holistic worldview and personal development as the main goal of the bachelor's degree, leaving other levels of the task of preparing for research innovation. Therefore, the course of technoethics at a technical university should be included in the basic component of training bachelors of all specialties and help specialists master the basics of moral regulation of both personal behavior and professional activity.

A modern technical university, positioned as a research university that prepares specialists capable of acting in a situation of uncertainty and constant innovation, should form moral competencies as the most important part of personal, general cultural and professional qualities. Thus, the course of technoethics becomes an element of the basic training of a specialist. The mastery of ethical regulation can occur both with the use of situations of technical incidents, and with the help of examples and exercises of general moral choice. Acquaintance and assimilation of the basic categories of moral choice, moral consciousness, grounds for ethically responsible decisions can be implemented using any examples of social practice, but with a mandatory indication of how these regulations work in engineering. For this, of course, it is necessary to develop modern educational and methodological teaching and monitoring tools workshops, business games, trainings, exercises, assignments, etc., which is an urgent problem of methodological support of the course of engineering ethics.

The complexity of modern moral consciousness dictates new forms of teaching engineering ethics. This should be not just a course of moralizing on the themes of engineering creativity, but a way of 
forming rational and ethically responsible thinking, which addresses the philosophical worldview, political consciousness, cultural competence, sociological analysis of society, and historical laws. Engineering ethics is turning into a new general professional course, based on knowledge about society and the optimal regulation of its development, it forms personal and social competencies as an essential element of modern professionalism, an integral part of which is the willingness to act in an ethically impeccable manner when making decisions and implementing technical projects - moral competence ...

Moral competence is important both for the visual justification of one's own behavior strategy, and for assessing the actions of colleagues and determining public opinion on socially significant problems. Moral competence as an element of professionalism is defined by the ability to think in ethical categories, conduct ethical discussion, discuss social and professional problems with the use of moral knowledge and moral assessments in order to understand each other and determine the strategy of optimal behavior to achieve social consensus and social well-being.

\section{Conclusion}

A course in engineering ethics at a technical university is the main means of forming the ethical consistency of a specialist. It is aimed at developing students' ethical thinking, mastering the procedures for the moral assessment of activities and rational choice from the point of view of the ideally possible. Therefore, it should not be reduced only to an analysis of the precedents of previous untenable decisions (Challenger, Chernobyl, Fukushima), although this is also important. To master the experience of professional activity, the formation of moral competence, it is important to be able to analyze not only previous decisions, but also to act in new situations, to determine morally responsible behavior as optimal in a situation of difficult choice.

\section{REFERENCES}

1. Technik und Ethik. Hrsg. von H. Lenk, G. Ropohl. Stuttgart: Reclam, 1987; http://www.asce.org/Leadership-andManagement/Ethics/Code-of-Ethics/; http://www.washingtonaccord.org/;http:// www.rusea.info/tree/?id=15.

2. Союз немецких инженеров (VDI) - 1856 год; Русское техническое об-щество - 1866 год, Всероссийский союз инженеров и техников - 1904 год.

3. Harris C.E., Pritchard M.S., Rabins M.J. Engineering Ethics: Concept and Cas-es. Wadsworth, Cengage Learning, 2009. P. 7.

4. Степин В.С., Горохов В.Г., Розов М.A. Философия науки и техники: Учеб. Пособие. М.: Гардарики, 1996. С. 385-386.

5. Горохов В.Г. Философия техники и инженерная этика // Этика инженера: через понимание к воспитанию. Ведомости прикладной этики. Вып. 42 / под ред. В.И. Бакштановского, В.В. Новоселова. Тюмень: НИИ ПЭ, 2013. С. 5960.

6. История, философия и методология науки и техники: учебник для магист-ров / Н.Г. Багдасарьян, В.Г. Горохов, А.П. Назаретян / Под общ. ред. Н.Г. Багдасарьян. М.: Изд-во «Юрайт», 2014. - 383 с.; с. 244-246.

7. http://vyspec.ru/struktura/vivodi.php (дата обращения 5.11.2013).

8. Рыбин В.А. Университет XXI века: Антропологические перспективы образования и культуры. М.: Книжный 
CURRENT RESEARCH JOURNAL OF PEDAGOGICS 2(6): 78-84, June 2021

DOI: https://doi.org/10.37547/pedagogy-crjp-02-06-16

ISSN 2767-3278

(C)2021 Master Journals

Crossref doi) 80 Google

Accepted 18 $8^{\text {th }}$ June, 2021 \& Published 23 $3^{\text {th }}$ June, 2021

дом «Либроком», 2012. С. 47.

9. Bakhromovich, Siddikov Ilyosjon, and Maxamadaliev Lutfillo. "Development of ecological culture in students in the process of education of history of uzbekistan." (2021). 